\title{
Stratigraphic modelling of carbonate platform-to-basin sediments (Maastrichtian to Paleocene) in the Eastern Desert, Egypt
}

\author{
C. Scheibner*, J. Kuss, R.P. Speijer \\ Universität Bremen, FB5, P.O.Box 330440, 28334 Bremen, Germany
}

Received 28 September 2001; accepted 21 March 2003

\begin{abstract}
In the Galala Mountains of the Eastern Desert, Egypt, carbonate platform and basin deposits have excellent exposure. These exposures show a late Campanian-early Paleocene rimmed platform evolving into a late Paleocene distally steepened ramp. We modelled the evolution of the platform-basin transition from the Maastrichtian to Selandian (68.7-59 Ma) with the 2-D stratigraphic simulation program PHIL and compared the modelled results with outcrop sections. Stratigraphic, facies, and environmental data are summarized and operate as input and control parameters for the computer simulation. The most important parameters that control the depositional geometries of the late Cretaceous mixed carbonate siliciclastic platform and the Paleogene carbonate platform are changes in relative sea level, sediment flux and initial topography. The simulation provides an understanding of platform growth and slope to basin deposition, particularly in areas of the platform that are poorly exposed or have been eroded. Moreover, the simulated geologic parameters like lithology, overall thickness and palaeowater depth closely resemble field and laboratory measurements of the individual sections. In an earlier study, the Maastrichtian slope angle was calculated to be $5-8^{\circ}$ and this was confirmed in this study. In this earlier study also the timing of the transition from a rimmed platform to a distally steepened ramp was established to be during latest Maastrichtian-early Paleocene. The present study shows that the rimmed platform persisted at least until the late Paleocene (59 Ma), as indicated by the relatively high slope angle of $6^{\circ}$.
\end{abstract}

(C) 2003 Elsevier B.V. All rights reserved.

Keywords: Galala Mountains; Egypt; Maastrichtian; Paleocene; sedimentation rates; stratigraphic modelling; platform-basin transition

\footnotetext{
* Corresponding author. Present address: Institut für Geowissenschaften, Universität Potsdam, Postfach 601553, 14415 Potsdam, Germany. Tel.: +49-331-9775071,

Fax: +49-331-9775060.

E-mail addresses: scheibner@geo.uni-potsdam.de (C. Scheibner), kuss@uni-bremen.de (J. Kuss),

jer@uni-bremen.de (R.P. Speijer).
}

\section{Introduction}

The area of the Galala Mountains (Eastern Desert, Egypt; Fig. 1) has been the focus of numerous studies, mostly dealing with its biostratigraphy and lithostratigraphy (e.g. Abdel Kireem and Abdou, 1979; Strougo et al., 1992; Strougo

0031-0182/03/\$ - see front matter (C) 2003 Elsevier B.V. All rights reserved. doi:10.1016/S0031-0182(03)00449-8 